\title{
The making of oncology: Helminthology as the cornerstone
}

\author{
K. Lalchhandama \\ Department of Zoology, Pachhunga University College, Aizawl 796oor, Mizoram, India
}

\begin{abstract}
Cancer is multifaceted and multifarious disease. The diversity of cancer is complicated by so many types of carcinogens. Remarkably, helminth parasites are among the first wellestablished cancer agents. It started with the celebrated discovery of a roundworm Gongylonema neoplasticum (more famously, but wrongly, as Spiroptera carcinoma) by Johannes Fibiger, only to show that Nobel Prize selection can be a fallible operation. After almost a century of scepticism, it is now conceded that helminths, other than G. neoplasticum, are truly carcinogenic. For the first time in history, the International Agency for Research on Cancer finally proclaimed in 2009 that three flukes, Schistosoma haematobium (urinary blood fluke), Clonorchis sinensis (Chinese liver fluke), and Opisthorchis viverrini (Southeast Asian liver fluke) are Group 1, i.e. fully proven, carcinogens. The first is the leading cause of bladder cancer, while the latter two are of that of the bile duct (cholangiocarcinoma). This is the story of how they came to be.
\end{abstract}

Key words: Cancer; carcinogen; cholangiocarcinoma; Clonorchis sinensis; Opisthorchis viverrini; Schistosoma haematobium.

\section{Received 6 March 2017 Accepted 25 March 2017 \\ *For correspondence $\bowtie$ chhandama@pucollege.edu.in}

\section{Introduction}

Johannes Fibiger shall be remembered for his Nobel Prize in Physiology or Medicine in 1926 for all the wrong reasons. He was selected for the award under controversial circumstances, and the reason for his award-the discovery of a roundworm Gongylonema neoplasticum (but which he zealously called Spiroptera carcinoma) as a cancer agent in rats-was incontrovertibly proved wrong ${ }^{[1]}$ It is now our general understanding that G. neoplasticum can cause tumours, because the target cells, squamous epithelial cells, are naturally prone to tumour and cancer formation, be it induced or spontaneous-but the round- worm itself is not carcinogenic. There are actually helminth parasites known to cause or be associated with the development of cancers. This is because the chronic inflammation induced by them, or by any antigen for that matter, can incite hostile cell division. Infections with the most prevalent helminths including Schistosoma mansoni, S. japonicum, Echinococcus granulosus, Strongyloides stercoralis, Fasciola hepatica, Taenia species, and Trichuris trichuria have been linked to the development of one or other form of cancer. ${ }^{[2][3][4]}$ There are in fact naturally carcinogenic worms. The larval stage called cysticercus fasciolaris of the tapeworm T. taeniaeformis causes cancer in wild rats. ${ }^{[1]}$ The first observation was by a French physician Amédée 
Borrel, who noticed in 1906 the possible association between cysticercus fasciolaris with mammary carcinoma of mice. ${ }^{[5]}$ A roundworm Spirocerca lupi, originally described by a SwedishGerman naturalist Karl Rudolphi (better with an appellation, the father of helminthology) in 1809, is the causative agent of cancer, specifically oesophageal sarcoma, in dogs. ${ }^{[6]}$ The first case of its carcinogenicity was reported in 1955."7]

In humans, three flukes belonging to the class Trematoda, namely Clonorchis sinensis, Opisthorchis viverrini, and Schistosoma haematobium, are established to cause cancer. The International Agency for Research on Cancer (IARC) Working Group on the Evaluation of Carcinogenic Risks to Humans, which had since 1994 been monitoring the scientific reports on the parasites, finally declared in 2009 that chronic infections with $S$. haematobium, $C$. sinensis, and $O$. viverrini are undeniably carcinogenic to humans; hence, are Group 1 (meaning extensively proven) carcinogens ${ }^{[8]}$ The IARC evaluation resolved thus that:

There is sufficient evidence in humans for the carcinogenicity of chronic infection with Opisthorchis viverrini. Chronic infection with Opisthorchis viverrini causes cholangiocarcinoma... is carcinogenic to $h u-$ mans (Group 1).

There is sufficient evidence in humans for the carcinogenicity of chronic infection with Clonorchis sinensis. Chronic infection with Clonorchis sinensis causes cholangiocarcinoma... is carcinogenic to humans (Group 1).

There is sufficient evidence in humans for the carcinogenicity of chronic infection with Schistosoma haematobium. Chronic infection with Schistosoma haematobium causes cancer of urinary bladder... is carcinogenic to humans (Group 1).

S. haematobium (as member of the genus Schistosoma) is among the most abundant parasites that infection humans, ${ }^{[9]}$ remaining specifi- cally as the major cause of bladder cancer (only next to tobacco smoking), ${ }^{[10]}$ and is also attributed to increased infection with HIV.[11] As of 2016, C. sinensis and O. viverrini are the second most common causes of liver cancer, after alcohol; with an estimated 35 million people being infected with C. sinensis, and 10 million people with O. viverrini. ${ }^{[12]}$

\section{The Urinary Blood Fluke}

Schistosoma haematobium is a water-borne blood fluke of humans. The disease schistosomiasis, caused by species of Schistosoma, has surpassed malaria as the most prevalent parasitic disease of humans. As of the latest WHO report in 2015, 218 million people contracted the infection. ${ }^{[9]}$ S. haematobium and S. mansoni are the major species, causing urinary and intestinal infections respectively. Of these, $S$. haematobium holds the records of being the first blood fluke discovered, the first helminth parasite known to cause cancer in humans, in addition to being known as one of the oldest human helminths.

\section{Discovery}

Bloody urine (haematurea) is a disease of old quite familiar in Ancient Egypt. The Egyptians called it Aaa (not an exclamation) not knowing the causative parasite, as evident from a number of papyri as old as 5,000 years. ${ }^{[13][14]}$ The legendary tradition in Egyptian medicine, mummification involves removal of internal organs, particularly the bladder and rectum, where parasites would normally be present, as such it would be next to a miracle to find preserved parasites in mummies. Such unlikely miracle did happen, as Marc Armand Ruffer, an English physician in Egypt, reported in 1910. He discovered parasite eggs from the kidneys of two mummies (out of six he investigated), which were dated to around 1,250-1,000 BCE.[15] Using a biochemical technique of enzyme-linked immunosorbent assay (ELISA), several mummies about 3,000 and 4,000 years old were confirmed to have the infection. ${ }^{[13 \mid}$ Yet, the oldest infection known was again revealed using ELISA, in an 
adolescent individual dated to more than 5,000 years old. ${ }^{[16[177]}$ The cause of haematuria remained a mystery for millennia.

In 1850, Abbas I, the Viceroy of Egypt, engaged a German physician Wilhelm Griesinger as Director of the Kasr el-Aini Hospital, a medical school in Cairo. Griesinger had chosen a 25year-old Theodor Maximillian Bilharz, a new physician-graduate from the University of Tubingen, and who had an eye for parasitic worms, to be his assistant. Bilharz readily made himself busy performing autopsies of dead soldiers. A golden opportunity arrived in 1851, which he savoured with a lasting glory. In one of the corpses, he recovered unusual worm from the portal vein of the urinary tract. A worm in the blood vessel was never known before, and was highly unexpected. He quickly wrote to his mentor at home in Tubingen, Karl Theordor von Siebold. His first correspondence dated 1 May 1851 contained a vivid description:

I found in the blood of the portal vein a number of long, white helminths which, with the naked eye, I considered to be nematodes, but soon recognized as something new. A look into the microscope revealed a splendid Distomum with a flat body and a spiral tail at least ten times as long as the body... the tail... was a continuation of the flat body of the worm itself, rolled sideways towards the stomach surface in a half canal; the forked blind end of the intestinal canal extended into it very plainly.

What then is this animal? In spite of its long tail, it probably cannot be called a cercaria, which is completely different, histologically and morphologically. [English translation from Grove. $\left.{ }^{[18]}\right]$

\section{Taxonomy}

Siebold knew exactly the importance of such discovery, and readily published Bilharz's letters in his (as an editor) journal Zeitschrift für wissenschaftliche Zoologie. Bilharz initially believed from his first specimen, which was an isolated rolled$\mathrm{p}$ male, to be some kind of roundworm. But he realised that the worm had its odd features, defying the diagnostic features of Nematoda. It had two mouth-like structures, a pointed tail, and a soft and flat body. Moreover, it was the flat body that was rolled up to form a cylindrical body creating a half-canal on the inside-for which he later coined the technical term gynaecophoric canal. To his higher astonishment, he discovered a female towards the end of May, which was by any mean a perfect definition of a roundworm, but which remain embedded in the canal of the male. As he exclaimed in hysteria, it was "a trematode, with separate sexes." By default, all nematodes are dioecious (separately sexed), and trematodes are monoecious (two-in-one sexed). His letter to Siebold on 28 August confirmed the discovery of a female fluke, writing, "You can imagine my surprise when I saw a trematode protruding from the frontal opening of the groove and moving back and forth; it was similar in shape as the first, only much finer and more delicate... [The female] was completely enclosed in the groove-shaped half canal of the male posterior, similar to a sword in a scabbard." "19] Bilharz's was the first discovery of the human blood flukes, what are now called Schistosoma, the most prevalent helminth parasites in humans. In his letter to Siebold on 1 December 1851, he baptised the new fluke as Distomum haematobium; ${ }^{[20]}$ Distomum, from Greek $\delta$ is (dis) for twice, and $\sigma \tau$ tón (stoma) for mouth, was a genus erected by Carl Linnaeus in 1857 for all flukes as they are apparently endowed with two mouths (but which we now know them as oral sucker and ventral suckers or acetabulum, are actually the holdfast organs). Bilharz dereved haematobium from Greek words $\alpha$ in $\alpha$ (aima) meaning blood, and ßíós (bios) meaning life; for its blood-duelling habit. His formal description with the nomenclature was published in $18522^{[21][22]}$

It is crucial to point out that Bilharz almost simultaneously discovered the second species. In one of his letters, he mentioned some of the eggs of the fluke as having terminal spines while some had lateral spines. ${ }^{[23]}$ Lateral spines are 
present only on those of another related fluke, which causes intestinal bilharzia. He even happened to note that his original urinary fluke was different from the intestinal fluke in its anatomy and number eggs. ${ }^{[24]} \mathrm{He}$ was that close to discovering another major blood fluke (now called Schistosoma mansoni, to be identified by its namebearer Patrick Manson half a century later), which in fact turns out to be the major helminth parasite of humans. With the new knowledge that the two mouths were not exactly mouths, Heinrich Meckel von Hemsbach wanted to rectify the misnomer and invented a new name Bilharzia haematobium in 1856 to honour the discoverer. Writing in his rather limited-circulation book Mikrogeologie: Ueber die Concremente im thierischen Organismus (Microgeology: The Composition of Animal Structure), he said, "The genus name Distoma should not be used, but be replaced with Billharzia [double $l$ is considered as a printing mistake]." 25$]$ He even introduced a popular medical term bilharzia or bilharziasis or bilharziosis for the disease. ${ }^{[26]}$

Possibly unaware of the off-the-shelf publication of Meckel von Hemsbach, another German David Friedrich Weinland gave a more technically-adorned generic name Schistosoma in 1858. He drew the name from two Greek words $\sigma x i \sigma \mu \alpha$, (schisma) meaning split, and $\sigma \tilde{\omega} \mu \alpha$ (sôma) meaning body, a very precise description indeed. ${ }^{\left[{ }^{[7]}\right.}$ An English zoologist Thomas Spencer Cobbold resurrected the name Bilharzia in 1859 from his elaborate examination of the helminth parasites of zoo animals that died at the British Zoological Society's Zoological Garden. ${ }^{[28]}$ Thence, a century-old battle on priority ensued. (An exhaustive treatment on the controversial nomenclature and discovery of the life cycle is scrupulously given by Grove. ${ }^{[29]}$ Z Zoologists generally advocated the rationality of Bilharzia, particularly on the ground of priority, which was persuasively voiced by a German parasitologist Hans Vogel. ${ }^{[30 \mid[31][32]}$ It was Vogel who submitted the case to the highest level, the International Commission on Zoological Nomenclature, which had come into full force since 1895, in 1938. ICZN took up the case on 21 April 1954, and made a divisive but irrevocable resolution- much to the disgust of Vogel and many zoologists-overriding its very priority law by stating:

OPINION 226 Suppression, under the Plenary Powers, of the generic name Bilharzia Meckel von Hembach, 1856, for the purpose of validating the generic name Schistosoma Weinland, 1858 (Class: Trematoda).

\section{RULING:-}

(1) The generic name Bilharzia Meckel von Hemsbach, 1856, is hereby suppressed for the purposes of the Law of Priority but not for those of the Law of Homonymy.

(2) The generic name Schistosoma Weinland, 1858, placed on the Official List of Generic Names in Zoology in Opinion 11 , is hereby confirmed in its position thereon.

(3) The generic name Bilharzia Meckel von Hemsbach, 1856, as suppressed under (1) above, and its junior homonym Bilharzia Cobbold, 1859, are hereby placed on the Official Index of Rejected and Invalid Generic Names in Zoology as Names Nos. 35 and $36 .{ }^{[33]}$

\section{Discovery of the life cycle}

Deciphering its life cycle was an excruciatingly strenuous task. After half a century of false trails and experimental blunders, the discovery of snails as the intermediate host by Scottish parasitologist-physician Robert Thomson Leiper in 1915 kicked start the research in the right direction. ${ }^{[34]}$ It happened during World War I when schistosomiasis was becoming a burden to the British soldiers who were fighting in Egypt. Leiper patriotically volunteered for a mission to unveil the mystery of the transmission. The mission's first investigation covered 8 February to 15 July 1915. Leiper found schistosome cercariae from four species of snails belonging to Bullinus (now Bulinus) and Planorbis, which were collected from El Marg canal near Cairo. Using these snails, he successfully transmitted the cercariae to mice, rats, guinea pigs, and monkey, proving that the snails are the intermediate hosts. As to 
the eradication, he optimistically asserted that it could be achieved within a few years by exterminating snails from the rivers, because "water is absolutely essential to bilharzia outside the body and that practically all water in Egypt comes from the Nile."

By 1916, Leiper could identify the snail species as Planorbis boissyi, Bullinus contortus, B. dybowski and B. innesi. He soon realised that he was working on not one but two species of the fluke, as noted by Bilharz, distinguished by a lateralspined egg (for Bilharzia mansoni) and terminalspined ones (for B. haematobium). He discovered that B. mansoni infects only P. boissyi, while B. haematobium infects only Bullinus species. ${ }^{[35]}$ In 1916, he gave a comparative description and introduced the new names Schistosoma mansoni, while retaining Schistosoma haematobium. ${ }^{[36]}$ (It should be noted that an Italian-British physician Louis Westenra Sambon had created the names Schistosomum mansoni and Schistosomum haematobium way back in $\left.1907 .{ }^{[37]}\right)$ But in a fit of conscience, he made a rational choice for Bilharzia over Schistosoma in 1931. He stressed that the term Schistosomus (now schistosoma reflexus) had been used since the early 19th century as a technical term for birth defect in cattle and other domesticated animals. And that it had already created confusion in medical literature under the disease schistosomiasis. ${ }^{[38]}$

\section{Discovery of the carcinogenicity}

Reginald Harrison, while working as Surgeon to the Liverpool Royal Infirmary, reported in 1889 an extraordinary frequency of carcinoma (tissue cancer originating from the epithelial cells) of bladder among Egyptians infected with S. haematobium. He observed that four people out of five cancer victims had bilharzia. ${ }^{[39]}$ But he did not suspect the parasite as the causative agent. The correlation between bilharzia and bladder tumour came to light from the works of a German physician Carl Goebel. Goebel reported a detailed surgical treatments of bladder tumour in 1903 . He noticed that not only bladder cancer was most frequent among the Arabs in Egypt, but also the tumours were most often associated with bilharzia. ${ }^{[40[41]}$ Another German physician Otto Zuckerkandl published Handbuch der Urologie (Handbook of Urology) in 1904 in which he showed "Bilharzia papillom" showing numerous calcified embryos in the stroma of the tumour. He even indicated that the eggs of the schistosome are responsible for the symptoms. ${ }^{[42]}$ In 1905 , Goebel came to the conclusion that carcinoma of bladder was due to bilharzia, ${ }^{[43][44]}$

The notion was reinforced by the report of Alexander Robert Ferguson, a Scottish professor of pathology at the Egyptian Government School of Medicine in Cairo, in 1911. Ferguson reported from his autopsies of forty cases that the most common cancer among Egyptians was bladder cancer associated with bilharzia. ${ }^{[45]}$ A collective analysis of clinical cases by English physicians Robert V. Dolbey and A.W. Mooro in 1924 among 671 Egyptian patients established beyond doubt that bladder cancer and bilharzia are intertwined ${ }^{[46]}$ The carcinogenicity was conclusively demonstrated by an Egyptian physician M.F. Sorour in $1929 . .^{[4]}$ Sorour reported that schistosome eggs act as irritant to induce both benign and malignant tumours. The benign tumours are papillomata or submucous lesions in the intestine; while the malignant ones are epithelioma, carcinoma, adenocarcinoma and endothelioma. He also indicated that cancer of the bladder due to bilharzia was from two to eleven times more common than pure cancer (carcinoma) of the bladder in Egypt. ${ }^{[41]}$

\section{The Chinese (Oriental) Liver Fluke}

Clonorchis sinensis is a food-borne liver fluke of human that infects the common bile duct and gall bladder, causing clonorchiasis. It is acquired from eating fish. Its body is that of a typical trematode structure, measuring $15-20 \mathrm{~mm}$ in length and 3-4 $\mathrm{mm}$ in width, dorso-ventrally flat and leaf-shaped, and has two suckers. It is the most common trematode infection in Asia, and still actively transmitted in Korea, China, Vietnam, and also in Russia, with 200 million people at constant risk. Clonorchiasis is indicated by jaundice, indigestion, biliary inflammation, bile duct obstruction, even liver cirrhosis, and on top 
of it all, cancers such as those of bile duct (cholangiocarcinoma) and liver (hepatocellular carcinoma) ${ }^{[48]}$ Cholangiocarcinoma is cancer of the epithelial cells, called cholangiocytes, of the bile ducts.

\section{Discovery}

Ancient Chinese had known the symptoms of clonorchiasis. The earliest evidence is from corpses buried in 167 BCE at Jiangling County of Hubei Province and the Warring States tomb of the western Han Dynasty. ${ }^{[49]}$ But two millennia had to pass to discover the parasite that caused such disease, and it was an almost simultaneous discovery by two Scottish physicians in India and Mauritius. James McConnell, professor of pathology and resident physician at the Medical College Hospital in Calcutta (now Kolkata), India, found the parasite from a twenty-year-old Chinese carpenter who died of liver problem on 8 September 1874 . He performed an autopsy the next day, and noticed that the corpse had swollen liver (hepatomegaly) and distended bile ducts, which he noted were obstructed by a large number of flukes. ${ }^{[50]}$ He published a descriptive account in the 21 August 1875 issue of The Lancet, reporting:

On incising the liver in different directions, it was noticed that small, dark, vermicular-looking bodies escaped onto the table, and on more careful examination these were clearly seen to protrude from the bile ducts, which, on being dissected, were found more or less obstructed by and containing them in large numbers, some lying free, others coiled up and either solitary or in groups of twos or threes within the biliary ducts. ${ }^{\left[{ }^{11]}\right.}$

Upon structural examination and comparison with the then known flukes Distoma hepaticum (now Fasciola hepatica) and D. lanceolatum (now Dicrocoelium lanceolatum), he noted that the new fluke was strikingly unique concluding that it must "constitute an entirely new species". [52]

In December the same year, a Chinese man died in the Civil Hospital at Port Louis, Mauritius. William MacGregor, Chief Medical Officer of Fiji (and later decorated as Lieutenant-Governor of British New Guinea, Governor of Newfoundland and Governor of Queensland), performed the autopsy and found a large number of flukes in the bile ducts. He further encountered more Chinese patients who were suffering from constant paralytic fits. A total of three of his eight patients died, from whom MacGregor recovered the same flukes (but wrongly ascribing their paralysis to the flukes). He reported a meticulous description in 1877 in the January issue of Glasgow Medical Journal, ${ }^{[53]}$ and 26 May 1877 issue of The Lancet. Soon after their initial discoveries, both McConnell and MacGregor knew better than to describe the new fluke by themselves. They communicated to the physician-zoologist Cobbold. Cobbold quickly learned that it was a case of identical but clearly novel species of fluke. ${ }^{[54]}$

\section{Taxonomy}

Cobbold wrote a one-page letter in the 18 September 1875 issue of The Lancet, in which he gave the name Distoma sinense (sinense for a Latinised word for Chinese). ${ }^{[5]}$ But in 1876, a German zoologist Rudolf Leuckart published a whopping 882-page book Die menschlichen Parasiten und die von ihnen herrührenden Krankheiten: ein Hand-und Lehrbuch für Naturforscher und Aerzte (The Human Parasites and their Diseases: A Manual and Textbook for Naturalists and Physicians). Apparently unaware of the small note of Cobbold (but then he was discussing the works of cobbold on $\mathrm{D}$. lanceolatum), he reflected the discovery of McConnell, and appreciated the uniqueness of the species. Writing on page 871, he rather bluntly concluded: "Dieselbe mag einstweilen hier als distomum spathulatum bezeichnet sein (The same may be described here as Distomum spathulatum)."[56] Apparently, Cobbold was not beside with joy himself upon such news, and defending his authority, he wrote (as commentary note to MacGregor's paper): 
The entozoon was subsequently named by me Distoma sinense in the pages of the same journal; but Professor Leuckart, unaware of this nomenclature, afterwards proposed for its specific recognition the term Distomum spatulatum [sic]. The former name must therefore be allowed to remain; and especially so since it has now been adopted by several writers on entozoa... I have in my possession a large number of specimens sent to me from Calcutta, and on comparing them with two of Dr Macgregor's flukes (kindly forwarded to me by Dr Clark), I have no hesitation in pronouncing them to be identical. ${ }^{[57]}$

In spite of the Chinese origin and pioneering discoveries by British and German scientists, Japanese scientists have much to boast about on the history of $\mathrm{C}$. sinensis. ${ }^{[58]}$ Kenso Ishizaka recorded the first case of clonorchiasis in Japan. He recovered the flukes from a farmer who died in Okayama in 1878.[59] The same year, McConnell again identified another infection in a Chinese cook from Hong Kong. Erwin von Baelz (or Bälz), a German physician at Tokyo University, reported the presence of similar flukes from an autopsy of a Japanese patient whose cause of death was recorded as pulmonary tuberculosis in 1883 . He recorded two different forms, naming the smaller, more pathogenic form as Distoma hepatis endemicum sive perniciosum, and the larger, a more benign form as D.h.e.s. innocuum. ${ }^{[60]}$ Earlier in January of that year, four Japanese physicians at Okayama hospital published a small pamphlet titled Observations on Distomae of Lung and Liver in which they described several cases of clonorchiasis. Isao Ijima, a zoologist at Japan Imperial University, reassessed the Okayama report with those of Baelz, giving a detailed description of new specimens from Okayama hospital in 1886 . He correctly redescribed them as the same species, but still inconveniently contracted the name to Distoma endemicum. In December 1885, he had dissected three cats, and from one he recovered 600 flukes very similar to those of human flukes. He realised that albeit stunning resemblances, the cat fluke should be considered as a distinct species. [61] Although he was mistaken, it was nonetheless a discovery that the same fluke can infect other mammals.

When a new genus Opisthorchis was created [later elaborated] by a French zoologist Raphaël Blanchard in 1895, ${ }^{[62]}$ Cobbold's species D. sinense was moved to the new genus because of shared characters with the other members. ${ }^{[63]}$ But further analyses by a German zoologist Arthur Looss, while serving as Professor of Biology and Parasitology at the British School of Medicine in Cairo, Egypt, showed that there were remarkable differences from the general features of Opisthorchis, particularly on the highly branched testes. He introduced a new genus Clonorchis (from Greek k $\lambda \omega \omega$, Klon meaning twig or branch, öpxıs, orkhis meaning testis) in 1907 to differentiate them from Opisthorchis, those that are with lobed testes. ${ }^{[64]}$ But following suit to Baelz, he fell into taxonomical pitfall by differentiating the larger species as Clonorchis sinensis, which are mostly found in China, and the smaller species as C. endemicum, found mostly in Japan. In 1911, Harujiro Kobayashi, physician at the Government Institute for Infectious Diseases of Tokyo Imperial University, argued that there were no significant differences to warrant them as separate species, asserting that the differences in sizes were due to the nature of the host and intensity of infection, and had nothing to do with the biology; thus, they were all C. endemicum. ${ }^{[65]}$ But he changed his mind a bit in 1912 by switching his preference to C. sinensis. ${ }^{[6]}$ He made further analysis in 1915 and 1917 and came to the conclusion that Looss' classification was loosely based on rather loose [pardon the puns] characters, and not of diagnostic features-there is one and only one species and that Clonorchis sinensis and $\mathrm{C}$. endemicus are synonymous. ${ }^{[67][68]}$

\section{Discovery of the life cycle}

Although McConnell in his first report ingeniously conjectured that the fluke is transmitted to humans from infected meat, fish, chicken, or vegetable, as Chinese-he remarked-"are well 
known to be 'filthy feeders' delighting in putrid messes of half-raw fish, \&c,"[51] the exact mode of transmission was far from obvious. The complete life cycle was enlightened by Japanese parasitologists with an initial disappointing research. In his 1887 paper, Ijima reported that he had surveyed the localities of the fluke-infested villages. His experimental attempts to grow the eggs in different snails were blatant failure. He suspected that the eggs of fluke from infected humans are released into ditches, from where they are transmitted to an intermediate host. Based on the already known case of $F$. hepatica that is transmitted by snails, he painstakingly dissected all available snails he could get, all but in vain. ${ }^{[61]}$

The revelation came from Kobayashi who made successful experiments in 1910. He discovered the larval stages (metacercariae) in freshwater fishes caught from Okayama, Köjo and Sanban areas. He first fed a kitten with infected fishes, Pseudorasbora parva and Leucogobia guntheri. Faecal examination after one month indicated the presence of eggs. On autopsy, the kitten was found to harbour "innumerable" flukes in its bile ducts, hepatic ducts, gall bladder, pancreas and intestine. He then fed two other kittens with L. guntheri. He sacrificed one of the kittens after one week to find immature flukes in the liver. The other kitten died after ten days, and he found its gall bladder and bile duct filled with immature flukes. He further experimented with six kittens and two adult cats, sacrificing them at different time intervals starting from three hours to forty days. He found flukes of increasing ages as the duration of infection extended. Noticing that his flukes were smaller in size, and comparing with larger specimens convinced him to conclude "that they all belonged to Clonorchis endemicus, and that the fishes mentioned are [the second] intermediate hosts of the parasite." He first reported his discovery in 1911, ${ }^{[65 \mid}$ and subsequently presented the same at the Second Biennial Congress of the Far Eastern Association of Tropical Medicine held at Hong Kong in 1912. ${ }^{[69]}$ In 1915, he further experimentally infected cats using encysted larvae in the fish, and also elucidated the complete develop- mental stages in the cat. He even suggested that snails, specifically Melania libertina (now Semisulcospira libertina), could be the first intermediate hosts. He inferred the hypothesis from the close resemblance between the encysted larvae from fish and those of unencysted larvae (cercariae) in the snails, which are again abundant in rivers and swamps where clonorchiasis was prevalent. ${ }^{[0]}$ The hypothesis was proved correct by Masatomo Muto in 1918. Muto demonstrated that cercariae from the snail Bythinia striatula could be transferred to the fish $P$. parva in which they form cysts. When dogs and mice were fed with the infected fish, they developed adult flukes. He also made epidemiological survey and found that clonorchiasis is prevalent only where these snails are present. ${ }^{[1][72]}$ Thus, snails were vindicated as the first intermediate hosts. ${ }^{[73 \mid[74]}$

\section{Discovery of the carcinogenicity}

Herbert Lindesay Watson-Wemyss, working as an Assistant Physicians at the Royal Infirmary of Edinburgh, made the first confirmed case of cancer associated with $\mathrm{C}$. sinensis infection in 1919. He performed an autopsy of a Chinese soldier of the French Colonial Army (Les Troupes Coloniales) and noted "a tumour about the size of a Tangerine orange was found on the upper surface of the right lobe of the liver... Section of the liver at almost any point resulted in the escape of flukes in numbers." The tumour was a carcinoma. ${ }^{[75]}$ In 1922, South African physicians A. Porter and J.H.H. Pirie reported an autopsy of a Chinese man. They noticed extensive liver damage (cirrhosis), with large number of $C$. sinensis in the surrounding tissue. The prominent nodules were confirmed as malignant adenocarcinoma. They suggested that cirrhosis was induced by the flukes that developed into carcinoma. ${ }^{[76}$

Frank Oldt, an American physician at the Canton Hospital, made an extensive report in 1927 in which he concluded that clonorchiasis is most often asymptomatic, but symptomatic cases are mostly associated with liver cancer, and regarded it as an "exciting cause of cancer."[77] Another Chinese man died of carcinoma in 1928, and was found to have heavy infection 
with C. sinensis in his bile ducts. E.G. Nauck and B. Liang described the tumour as the "size of a child's head." ${ }^{[78]}$ In 1931, J. Heine gave an elaborate analysis of autopsy records in Shanghai Hospital, and noted that liver carcinoma is almost always associated with $C$. sinensis infection. ${ }^{[9]}$ A medical report of the Vancouver General Hospital, British Columbia, covering a period between 1932 and 1944 revealed that there were four cases of autopsies of Chinese men, all of whom had both liver carcinoma and clonorchiasis. $^{[80]}$ Population-based studies in the early 1970s formed the definitive circumstantial evidences that $\mathrm{C}$. sinensis is carcinogenic. ${ }^{[81][82][83]}$

\section{The Southeast Asian Liver Fluke}

Opisthorchis viverrini is another food-borne liver fluke that infects the bile ducts. Its features are similar to those of $C$. sinensis, and is transmitted from fish via snails. Its infection, opisthorchiasis, is associated with a number of hepatobiliary abnormalities, including hapatocarcinoma (liver cancer), cholangitis, obstructive jaundice, hepatomegaly, periductal fibrosis, cholecystitis and cholelithiasis. ${ }^{[84]}$ In Southeast Asia it is the leading cause of bile duct cancer (cholangiocarcinoma), which in turn is the leading cause of mortality, especially in northern Thailand. It is estimated that 5,000 cases of cholangiocarcinoma are diagnosed annually in northern Thailand, and the same figure goes for the number of death due to liver-related death. [85] However, it is only endemic in the Mekong River Basin, covering northern Thailand, some parts of the Lao People's Democratic Republic, Vietnam and Cambodia. ${ }^{[86][87][88]}$

\section{Discovery}

O. viverrini was discovered by French parasitologist M.J. Poirier in 1886 . He obtained the first specimen from the bile duct of an Indian fishing cat (Felis viverrini, now Prionailurus viverrinus), which was originally captured from Southeast Asia. The cat was found dead at the Zoological Gardens attached to the National Museum of Natural History in Paris. Following the general system of taxonomy of trematodes having two mouth-like suckers, he gave the name Distomum viverrini. ${ }^{[89}[90]$ It is important to discuss the species with other related species, because the medical implications are hugely overlapping. There was no clear distinction because of their high resemblance, both in their biology and pathological effects. The first cat liver fluke discovered was in fact by an Italian zoologist Sebastiano Rivolta in 1884 from northern Italy. He named it Distomum felinium. [91] The first report of human infection by the same species was made by a Russian parasitologist Konstantin Nikolaevich Vinogradov in 1891 from Siberia. ${ }^{[92]}$ By the 1890s, the American Ornithologist's Union (A.O.U.) Code (later incorporated into the International code of Zoological Nomenclature) had become the authoritative system of naming zoological species. Based on it, an overhaul of taxonomic revision was imperative.

In 1985, Blanchard systematically argued that many species classified under the genus Distomum in fact required a separate genus. He therefore created Opisthorchis (from Greek prefix ónı $\odot \circ-$, opistho- meaning back, rear, or posterior, and orkhis meaning testis). ${ }^{[62]}$ Using D. felinium (that become Opisthorchis felinium) as the type species, he renamed $O$. conjunctus (Cobbold, 1860), O. buski (Lankester, 1857), and O. sinensis. But then he was not without foibles. O. conjunctus and 0 . buski were redescribed by Looss in 1899, assigning new systematic positions $\mathrm{Me}$ torchis conjunctus and Fasciolopsis buski respectively. ${ }^{[93]}$ Looss again moved $O$. sinensis to Clonorchis sinensis in 1907.[64] Following Blanchard, two American parasitologists Charles Wardell Stiles and Albert Hassall also made an extensive revision of many helminth parasites in 1896. Among them were three closely related flukes Distomum truncatum, D. albidum, and D. felinium. After analytical redescription of the specimens, they moved these species to the genus Opisthorchis, and changed $D$. felinium to its final resting name Opisthorchis felineus. ${ }^{94]}$

\section{Discovery of the life cycle}

Elucidation of the complete life cycle of $O$. 
felineus took three decades in fits and starts. The first hunch for the second intermediate host was from a German-Swiss pathologist Max Askanazy in 1905. He demonstrated that the cercariae could be experimentally transmitted by feeding dogs with uncooked fish of the family Cyprinidae, specifically Idus melanotus (chub) and Leuciscus rutilus (roach). ${ }^{[95]}$ But his species identification was later questioned. It was a Romanian zoologist J. Ciurea who in 1917 made a conclusive evidence that larval transmission of $\mathrm{O}$. felieus could occur from fish, such as Tinca tinca and Idus idus, to dogs and cats. ${ }^{[96]}$ The German parasitologist Hans Vogel discovered snails as the first intermediate host in 1932. He observed the infection of $O$. felineus miracidia in the snail Bythinia leachi, and unveiled the complete development into cercariae. ${ }^{[97]}$ In 1937 , he established the complete life cycle through the second intermediate host Tinea vulgaris. ${ }^{[98]}$

The earliest account of possible opisthorchiasis due to $O$. viverrini was reported by two French medical zoologists Paul Verdun and L. Bruyant, at the Faculté de Médecine de Lille, in 1907 and 1908. They claimed a recovery of $O$. felineus from a patient in Token in northern Vietnam. ${ }^{[99][100]}$ Although it was more likely 0 . viverrini, nothing could be confirmed due lack of preserved specimen. The first undisputed human specimen of $O$. viverrini (from historical reassessment) was described by a parasitologist Robert Thomson Leiper in 1915. Leiper, a LieutenantColonel of the Royal Army Medical Corps at the London School of Tropical Disease, received three specimens (among other things) from an Irish medical doctor Arthur Francis George Kerr, who had collected them from an autopsy of two prisoners at a jail in Chiang Mai, northern Thailand. Kerr, although labelling them as O. felineus, noticed some differences and self-doubted, which led him to scribble:

Opisthorchis felineus? Ova found in about fifteen per cent. of the faeces examined. The worms were twice obtained post mortem, in one case a single one from the intestine in another twelve worms from the gall bladder and large bile-ducts. The ova have a small projection at the distal end, the cap. The worms also differ from the figures I have of Opisthorchis felineus in having much larger part of the intestine unbranched, they also seem smaller. I was present at a post-mortem by Dr. Mason where thousands of these worms were removed from the liver.

Upon more careful examination, Leiper was convinced of the differences and noted that "the skin is covered with minute acicular spinelets; the ovary is multilobulate; the branches of the gut proceed almost to the extreme posterior end of the body. The ovary and testes fill the last fourth of the body between the gut branches." He concluded, with a prophetic statement on its transmission, "I therefore make a provisional diagnosis of $O$. viverrini, a parasite found in the Indian civet cat, but not recorded heretofore from man. Infection is probably acquired from the consumption of uncooked or partially cooked freshwater fish." ${ }^{[101]}$ In the next year Kerr himself reported from investigation of 230 male prisoners that $39(17 \%)$ of them had the infection. Even though they comprised of different ethnicity, Laos, Shan, and Karen, all of them were residents of Chiang Mai. ${ }^{[102][103]}$ Thai pathologist Chalerm Prommas also reported o. felineus in 1927 from an autopsy of a 17-year-old Thai male residing in Roi-et, northeast Thailand. [104] The first report from Laos was in 1929. E. Bedier and $\mathrm{P}$. Chesneau found the parasite in the bile ducts of three corpses in Thakhek town, and numerous stool samples in the town indicated the presence of the parasite eggs. In Thakhek, $23 \%$ of 1231 samples were positive, and in Vientiene, $15 \%$ of 523 were infected. ${ }^{105]}$

Elvio H. Sadun from the U. S. Public Health Service started conducting epidemiological survey of parasitic infections in Thailand in 1953, and immediately found that $O$. viverrini was disproportionately abundant in the northeast area. [106] The next year he found that not only humans, but also cats and dogs were naturally infected. His important note was that "infection was produced by feeding cats on some of the common raw fish dishes sold in the market for 
human consumption."[107] Thai physicians Suvajra Vajrasthira and Chamlong Harinasuta found in 1960 that the cercariae were present only in the snail species of Bithynia. ${ }^{[108]}$ The two men with the help of a Japanese Yoshitaka Komiya demonstrated cyprinid fish of the species Cyclocheilicthys as the second intermediate hosts in 1961. ${ }^{[109]} \mathrm{A}$ systematic comparison and elucidation of its transmission in 1965 confirmed the differences from 0 . felineus, as well as its complete life cycle..$^{[110]}$ The distinction between 0 . felineus and 0 . viverrini was firmly established after the complete understanding of their geographical distributions. O. felineus is dominantly found in Europe, and some parts of northern Asia, ${ }^{[111]}$ whereas $O$. viverrini is strictly the parasite in Southeast Asia. ${ }^{[85 \mid[103]}$

\section{Discovery of the carcinogenicity}

Early in 1900, Askanazy had made a study on the possible link between $O$. felineus and human liver cancer in East Prussia. ${ }^{[122]}$ The first report of the link between $O$. viverrini and cancer was in 1953. Thai physicians Vikit Viranuvatti and Sorn Mettiyawongse, at the Siriraj University Hospital in Bangkok, reported two cases of 0 . viverrini infections, which they had started investigating since 1948. They diagnosed liver carcinoma, and suspected that the cancer was associated with the infection, and claimed that theirs was the first "report of the occurrence of carcinoma of the liver in cases of infection with Opisthorchis viverrini."[113] But isolated cases did not evince convincing evidence. The clear correlation between 0 . viverrini and cholangiocarcinoma emerged in the mid-1950s. The first clinical case was reported by Viranuvatti, Dhanyasobhak Kshemsant, and Natth Bhamarapravati from an autopsy of a cancer patient in 1955. They found that carcinoma was most probably due to opisthorchiasis. ${ }^{[114]}$ The first epidemiological evidence was expressed by Sadun in 1955. He found that 0 . viverrini infection was extremely prevalent in northern Thailand. He made a precise observation that the neighbouring Chinese who consume the same fish never got an infection because they cooked them thoroughly. He pre- sented the clinical symptoms as general malaise, abdominal discomfort, and occasional diarrhoea. This was sometimes followed by pain at the site of the liver, transient urticaria, and jaundice. In four men having opisthorchiasis, he confirmed carcinoma of the bile ducts. However, he prudently concluded that "Whether or not the association between liver fluke infection and carcinoma of the bile ducts was a causal relationship could not be determined by the present studies." $[115]$ The population-based epidemiological survey in early 1990s confirmed the correlation in Thailand, with the conclusion that cholangiocarcinoma is most prevalent in northeast region, specifically Khon Kaen, where opisthorchiasis is most prevalent. ${ }^{[16 \mid[117]}$

\section{References}

I. Lalchhandama, K. (2017). The making of oncology: The tales of false carcinogenic worms. Science Vision. I7 (I): $33-52$.

2. Fried, B.; Reddy, A.; Mayer, D. (201I). Helminths in human carcinogenesis. Cancer Letters. 305 (2): 239-249. doi:Io.IoI6/j.canlet.2010.07.008

3. Kutikhin, A. G.; Yuzhalin, A. E.; Brusina, E. B. (2013). The Role of Helminthes and Fungi in Cancer Development. Infectious Agents and Cancer. Dordrecht (Netherlands): Springer Science+Business Media. ISBN 978-94-007-5954-I. doi:I0.1007/978-94-007-59558_5

4. Machicado, C.; Marcos, L. A. (2016). Carcinogenesis associated with parasites other than Schistosoma, Opisthorchis and Clonorchis: $A$ systematic review. International Journal of Cancer. 138 (I2): 2915-292I. doi:I0.I002/ijc.30028

5. Borrel, A. (1906). Tumeurs cancereuses et helminthes [Cancerous tumours and helminths]. Bulletin de l'Académie nationale de médecine. 56: I4I-I45.

6. van der Merwe, L.L.; Kirberger, R.M.; Clift, S.; Williams, M.; Keller, N.; Naidoo, V. (2008). Spirocerca lupi infection in the dog: A review. The Veterinary Journal. 176 (3): 294-309. doi:I0.I0I6/j.tvjl.2007.02.032

7. Seibold, H. R.; Bailey, W. S.; Hoerlein, B. F.; Jordan, E. M.; Schwabe, C. W. (1955). Observations on the possible relation of malignant esophageal tumors and Spirocerca 
lupi lesions in the dog. American Journal of Veterinary Research. 18 (58): 5-I4.

8. IARC Working Group (2012). A Review of Human Carcinogens: Part B: Biological Agents (IARC Monographs on the Evaluation of Carcinogenic Risks to $\mathrm{Hu}$ mans Volume $100 \mathrm{~B}$ ). Lyon (France): International Agency for Research on Cancer. pp. 34I-384. ISBN 97892-832-1319-2

9. Anon. (2017). Schistosomiasis. WHO Fact Sheet. WHO Media Centre. Retrieved 16 February 2017. http:// www.who.int/mediacentre/factsheets/fsirs/en/

Io. Antoni, S.; Ferlay, J.; Soerjomataram, I.; Znaor, A.; Jemal, A.; Bray, F. (2017). Bladder Cancer incidence and mortality: A global overview and recent trends. European Urology. 7I (I): 96-Io8. doi:Io.IoI6/ j.eururo.2016.06.o10

II. Le, L.; Hsieh, M. H. (January 2017). Diagnosing urogenital schistosomiasis: Dealing with diminishing returns. Trends in Parasitology. Online: SI47I-4922(I6) 3023I-8. doi:Io.IoI6/j.pt.2016.12.009

I2. Zheng, S.; Zhu, Y.; Zhao, Z.; Wu, Z.; Okanurak, K.; Lv, Z. (2016). Liver fluke infection and cholangiocarcinoma: a review. Parasitology Research. II6 (I): II-I9. doi:10.1007/s00436-016-5276-y

I3. Contis, G.; David, A.R. (1996). The epidemiology of Bilharzia in Ancient Egypt: 5000 years of schistosomiasis. Parasitology Today. I2 (7): 253-255. doi:Io.IoI6/or69 -4758(96)30007-0

14. David, A. R. (2000). 5000 years of schistosomiasis in Egypt. Chungará (Arica). 32 (I): 133-135. doi:10.4067/ So717-73562000000100022

I5. Ruffer, M.A. (1910). Note on the presence of Bilharzia haematobia in Egyptian mummies of the twentieth dynasty [1250-1000 BC]. British Medical Journal. I (2557): 16 .

16. Deelder, A.M.; Miller, R.L.; de Jonge, N.; Krijger, F.W. (1990). Detection of schistosome antigen in mummies. The Lancet. 335 (869I): 724-725.

17. Barakat, R.M.R. (2013). Epidemiology of schistosomiasis in Egypt: Travel through time: Review. Journal of Advanced Research. 4 (5): 425-432. doi:Io.IoI6/ j.jare.2012.07.003

18. Grove, D.I. (1990). A History of Human Helminthology. Wallingford, Oxon (UK): C.A.B. International. p. I88. ISBN 978-0-85198-689-0
19. Bilharz, T.; Siebold, C.T. (1852). Ein Beitragzur Helminthographia humana, aus brieflichen Mittheilungen des Dr. Bilharz in Cairo, nebst Bermerkungen von Prof. C. Th. von Siebold in Breslau. Zeitschrift für wissenschaftliche Zoologie. 4: 53-76.

20. Farley, J. (2003). Bilharzia: A History of Imperial Tropical Medicine. Cambridge (UK): Cambridge University Press. pp. 48-50. ISBN 9780521530606

2I. Bilharz, T. (1852). Fernere Mittheilungen uber Distomum haematobium. Zeitschrift für wissenschaftliche Zoologie. 4: 454-456.

22. Rabello, A. (1997). Diagnosing schistosomiasis. Memórias do Instituto Oswaldo Cruz. 92 (5): 669-676. doi:10.1590/Soo74-0276199700050002I

23. Lofty, W.M. (2009). Human schistosomiasis in Egypt: Historical review, assessment of the current picture and prediction of the future trends. Journal of the Medical Research Institute. $30(\mathrm{I})$ : I-7.

24. Akl, M.M. (2009). Bilharziasis: A Granulomatous Parasitic Disorder with Grave Implications. In Mansourian, B.P.; Wojtczak, A.; Sayers, B.M. Medical Sciences - Volume I. Oxford (UK): Eolss Publishers Co. Ltd. pp. 374400. ISBN 978-I-84826-733-6

25. Meckel von Hemsbach, H. (1856). Mikrogeologie: Ueber die Concremente im thierischen Organismus. Berlin (Germany): Druck und Verlag von Gerog Reimer. p. II4.

26. Mutapi, F. (2016). Getting a GRiPP on everyday schistosomiasis: experience from Zimbabwe. Parasitology. Online: I-9. doi:Io.IOI7/Soo3II8201600I724

27. Weinland, D.F. (1858). Human Cestodes: An Essay on the Tapeworms of Man. Cambridge (UK): Cambridge University Press. pp. 23-24.

28. Cobbold, T. S. (1859). XXVII. On some new forms of Entozoa. Transactions of the Linnean Society of London. 22 (4): 363-366. doi:Io.III//j.I096-3642.I856.tbooro5.x

29. Grove, D. I. Ibid. pp. 189-205.

30. Vogel, H. (1947). On the relative status of the names Bilharzia Meckel von Hemsbach, 1856, and Schistosoma Weinland, 1858 (Class Trematoda, Order Digenea). Bulletin of Zoological Nomenclature. I (9): 193-I94.

31. Hemming, F. (1947). On the status of the generic name Schistosoma Weinland, I858 (class Trematoda, order Digenea) in relation to Opinion 77. The Bulletin of 
Zoological Nomenclature. I (9): 195.

32. Brock, G.S. (1894). On the bilharzia hæmatobia. The Journal of Pathology and Bacteriology. 2 (I): 52-74. doi:I0.I002/path.I700020105

33. Hemming, F. (editor) (1954). Opinions and Declarations Rendered by the International Commission on Zoological Nomenclature (Volume 4 Part 16). London (UK): International Trust for Zoological Nomenclature. pp. I77200.

34. Leiper, R.T. (1915). Report on the results of the Bilharzia Mission in Egypt, 1915. Journal of the Royal Army Medical Corps. 25 (2): I-55, I47-192.

35. Leiper, R.T. (1915). Report on the results of the Bilharzia Mission in Egypt, 1915. Part IV.- Egyptian Mollusca. Journal of the Royal Army Medical Corps. 27 (2): I7II90.

36. Leiper, R.T. (1916). On the relation between the terminal-spined and lateral-spined eggs of bilharzia. The British Medical Journal. I (288I): 4II.

37. Sambon, L.W. (1907). Remarks on Scbistosomum mansoni. Journal of Tropical Medicine and Hygiene. 10: 303 -304 .

38. Leiper, R.T. (193I). Schistosome worms and schistosome monsters. The British Medical Journal. I (3670): 817.

39. Harrison, R. (I889). Specimens of Bilharzia affecting the urinary organs. The Lancet. 2: 163.

40. Goebel, C. (1903). Erfahrungen über die chirurgische Behandlung der Cystitis und der Blasentumoren bei Bilharziakrankheit [Experiences on the surgical treatment of cystitis and bladder tumours in bilharzial disease]. Deutsche Zeitschrift für Chirurgie. 66 (3-4): 223245. doi:I0.1007/BFo2790883

4I. Brumpt, E. (1930). Rôle des bilharzies dans la production de certains cancers [Role of bilharzia in the production of certain cancers]. Annales de Parasitologie Humaine et Comparée. 8: 75-IOI.

42. Zuckerhandl, O. (1904). Handbuch der Urologie Volume I. Vienna (Austria): Alfred Hölder. p. 748.

43. Goebel, C. (1905). Ueber die bei Bilharziakrankheit vorkommenden Blasentumoren mit besonderer Berücksichtigung des Carcinoms [On the bladder tumors occurring in bilharzia, with special consideration of carcinoma]. Zeitschrift für Krebsforschung. 3 (3): 369-513. doi:10.1007/BFo2215122
44. Berry, A.; Iriart, X.; Fillaux, J.; Magnaval, J.-F. (20I7). Schistosomose urogénitale et cancer [Urinary schistosomiasis and cancer]. Bulletin de la Société de pathologie exotique. IIо (I): 68-75. doi:I0.I007/sI3149-0I7-0547-4

45. Ferguson, A. R. (I9II). Associated bilharziosis and primary malignant disease of the urinary bladder, with observations on a series of forty cases. The Journal of Pathology and Bacteriology. 16 (I): 76-94. doi:Io.Ioo2/ path.I700160107

46. Dolbey, R.V.; Mooro, A.W. (1924). From the Royal School of Medicine, Cairo. The incidence of cancer in Egypt. The Lancet. 203 (5247): 587-590. doi:Io.IoI6/ Sol40-6736(00)56054-I

47. Sorour, M.F. (1929). Contribution a l'étude des tumeurs irritatives bénignes et malignes produites par les bilharzies [Contribution to the study of benign and malignant irritative tumors produced by bilharzias]. Annales de Parasitologie Humaine et Comparée. 7: 381-98.

48. Hong, S-T; Fang, Y. (20I2). Clonorchis sinensis and clonorchiasis, an update. Parasitology International. 6I (I): 17-24. doi:Io.IoI6/j.parint.20II.06.007

49. Dexiang, W.; Wenyuan, Y.; Shenqi, H.; Yunfang, L.; Tiancheng, S.; Jiahua, M.; Wenxiu, H.; Nianfeng, X. (198I). Parasitological investigation on the ancient corpse of the Western Han Dynasty unearthed from tomb No. 168 on Phoenix Hill in Jiangling county. Acta Academiae Medicinae Wuban. I (2): 16-23. doi:Io.1007/ BFo2857069

5o. Grove, D.I. (1990). ibid. pp. I4I-158.

5I. McConnell, J.F.P. (1875). Remarks on the anatomy and pathological relations of a new species of liver-fluke. The Lancet. 106 (2712): 271-274. doi:Io.IoI6/SoI40-6736(o2) 30525-7

52. Qian, M-B; Utzinger, J; Keiser, J; Zhou, X-N (2016). Clonorchiasis. The Lancet. 387 (I0020): 80o-810. doi:10.1016/Sor40-6736(I5)60313-0

53. MacGregor, W. (1877). A new form of paralytic disease associated with the presence of a new species of liver parasite. Glasgow Medical Journal. 9 (I): 3-15.

54. Cobbold, T.S. (1879). Parasites: A Treatise on the Entozoa of Man and Animals, Including Some Account of the Ectozoa. London (UK): J. \& A. Churchill. pp. 2830 .

55. Cobbold, T. S. (I875). The new human fluke. The Lancet. 106 (2716): 423. doi:Io.IoI6/SoI40-6736(02)48496-6 
56. Leuckart, R. (1876). Die menschlichen Parasiten und die von ibnen herrübrenden Krankbeiten: ein Hand-und Lebrbuch für Naturforscher und Aerzte. Zweiter Band. Leipzig and Heidelberg (Germany): C.F. Winter'sche Verlagshandlung. p. 87I.

57. Cobbold, T.S. (1877). Appendix: A new form of paralytic disease associated with the presence of a new species of liver parasite. Glasgow Medical Journal. 9 (I): I6.

58. Yoshida, Y. (2012). Clonorchiasis-A historical review of contributions of Japanese parasitologists. Parasitology International. 6I (I): 5-9. doi:Io.IoI6/ j.parint.2011.06.003

59. Ishizaka, K. (1878). Records on an autopsy case. Igaku Zasshi. 40: 20-26.

6o. Baelz, E. (1883). Über einige neue Parasiten des Menschen [About some new parasites of man]. Berliner klinische Wochenschrift. 20: 234-238.

6I. Ijima, I. (1887). Notes on Distoma endemicum, Baelz. The Journal of the Science College of the Imperial University. I (I): 47-59.

62. Blanchard, R. (1895). Animaux parasites (Notice préliminaire). Bulletin de la Sociét é Zoologique de France. 20: 217 .

63. Bisseru, B. (1957). On the genus Opisthorchis R. Blanchard, I895, with a note on the occurrence of O.geminus (Looss, I896) in new avian hosts. Journal of Helminthology. 3I (3): 187-202.

64. Looss, A.; Cuffey, E. (1907). Some parasites in the Museum of the School of Tropical Medicine, Liverpool. Annals of Tropical Medicine \& $\mathcal{C}$ Parasitology. I (I-5): $\mathrm{I} 22$ -I57. doi:10.1080/00034983.1907.11719254

65. Kobayashi, H. (19II). A preliminary report on the source of the human liver distome, Clonorchis endemicus [Bälz] [=Distoma spatbulatum Leuckart]. Annotationes Zoologicae Japonenses. 7 (5): 27I-277.

66. Kobayashi, H. (1912). Studies on Clonorchis sinensis (original report). Nippon Saikin-Gaku Zasshi (Japanese Journal of Bacteriology). 202: 597-662.

67. Kobayashi, H. (1915). On the life-history and morphology of Clonorchis sinensis. Zentralblatt für Bakteriologie, Parasitenkunde, Infektionskrankheiten und Hygiene. 75 (4): 299-318.

68. Kobayashi, H. (1917). On the life-history and morphology of the liver distome Clonorchis sinensis. Mitteilun- gen aus der Medizinischen Fachschule zu Keijo. I: 25I284.

69. Kobayashi, H. (1912). A preliminary report on the source of the human liver distome, Clonorchis endemicus [Bälz] [=Distoma spatbulatum Leuckart]. In Clark, F. Far Eastern Association of Tropical Medicine: Transactions of the Second Biennial Congress Held at Hongkong, IgI2. Hongkong: Noronha. pp. Io8-II2.

70. Kobayashi, H. (1915). On the life-history and morphology of Clonorchis sinensis. Zentralblatt fur Bakteriologie, Parasitenkunde, Infektionskrankheiten und Hygiene. 75 (4): 299-318.

7I. Muto, S. (1918). On the primary intermediate host of Clonorchis sinensis. Chuo Igakkai Zasshi. 25: 49-52.

72. Muto, M. (1918). Über den ersten Zwischenwirt von Clonorchis sinensis [On the first intermediate host of Clonorchis sinensis]. Verhandlungen der Japanischen Pathologischen Gesellschaft. 8: I5I.

73. Sripa, B.; Tesana, S.; Yurlova, N.; Nawa, Y. (2017). A historical review of small liver fluke infections in humans. Parasitology International. Online. doi:Io.IoI6/ j.parint.2017.01.004

74. Yoshitaka, K, (1967). Clonorchis and clonorchiasis. In Dawes, B. Advances in Parasitology Volume 4. Burlington (US): Elsevier. pp. 53-IOI. ISBN 978-0-08-058050-0

75. Watson-Wemyss, H. L. (1919). Carcinoma of the liver associated with infection by Clonorchis sinensis. Edinburgh Medical Journal. 22 (2): 103-IO4.

76. Porter, A.; Pirie, J.H.H. (1922). Clonorchis sinensis, the human liver fluke, found in a Chinaman in Johannesburg, with notes on the pathology of the case. Medical Journal of South Africa. I7 (I2): 240-244.

77. Oldt, F. (1927). Is clonorchis a health menace in China? China Medical Journal. 4I (3): 185-204.

78. Nauck, E.G.; Liang, B. (1928). Primarer leberkrebs und Clonorchis infektion [Primary liver cancer and Clonorchis infection]. Archiv für Schiffs-und Tropen-Hygiene. 32: 109-II6.

79. Heine, J. (1931). Cancer in Chinese. Zeitschrift für Krebsforschung. 33: 529-554.

8o. Strong, G. F.; Pitts, H. H.; McPhee, J. G. (1949). Primary carcinoma of the liver-25 year study. Annals of Internal Medicine. 30: 79I-798.

8I. Gibson, J.B. (1971). Parasites, liver disease and liver can- 
cer. Liver Cancer, I. A. R. C. Scientific Publ. No. I. Lyon (France): WHO and International Agency for Research on Cancer. p. 7.

82. Kim, Y. I.; Yang, D. H.; Chang, K. R. (1974). Relationship between Clonorchis sinensis infestation and cholangiocarcinoma of the liver in Korea. Seoul Journal of Medicine. 15: 247-253.

83. Chung, C.C.; Lee, S.K. (1976). An epidemiological study of primary liver carcinomas in Busan Area with special reference to clonorchiasis. Korean Journal of Pathology. Io (I): $33-46$.

84. Sripa, B.; Kaewkes, S.; Sithithaworn, P.; Mairiang, E.; Laha, T.; Smout, M.; Pairojkul, C.; Bhudhisawasdi, V.; Tesana, S.; Thinkamrop, B.; Bethony, J. M.; Loukas, A.; Brindley, P. J. (2007). Liver fluke induces cholangiocarcinoma. PLoS Medicine. 4 (7): e2or. doi:Io.I37I/ journal.pmed.oo4020I

85. Sripa, B.; Brindley, P. J.; Mulvenna, J.; Laha, T.; Smout, M. J.; Mairiang, E.; Bethony, J. M.; Loukas, A. (20I2). The tumorigenic liver fluke Opisthorchis viverrini multiple pathways to cancer. Trends in Parasitology. 28 (Iо): 395-407. doi:I0.IoI6/j.pt.2012.07.006

86. Dao, T.T.H.; Bui, T.V.; Abatih, E.N.; Gabriël, S.; Nguyen, T.T.G.; Huynh, Q.H.; Nguyen, C. Van; Dorny, P. (2016). Opisthorchis viverrini infections and associated risk factors in a lowland area of Binh Dinh Province, Central Vietnam. Acta Tropica. 157: I5I-I57. doi:Io.IoI6/j.actatropica.2016.0I.029

87. Sohn, W-M.; Yong, T-S.; Eom, K.S.; Pyo, K-H.; Lee, M.Y.; Lim, H.; Choe, S.; Jeong, H-G.; Sinuon, M.; Socheat, D.; Chai, J-Y. (2012). Prevalence of Opisthorchis viverrini infection in humans and fish in Kratie Province, Cambodia. Acta Tropica. 124 (3): 215-220. doi:Io.IoI6/j.actatropica.20I2.08.oII

88. Miyamoto, K.; Kirinoki, M.; Matsuda, H.; Hayashi, N.; Chigusa, Y.; Sinuon, M.; Chuor, C. Meng; Kitikoon, V. (2014). Field survey focused on Opisthorchis viverrini infection in five provinces of Cambodia. Parasitology International. $63 \quad$ (2): 366-373. doi:Io.IoI6/ j.parint.2013.12.003

89. Poirier, J. (I886). Trematodes nouveaux ou peu connus [New or little known trematodes]. Bulletin de la Société Philomathique de Paris. 10 (I): 20-40.

9o. Saijuntha, W.; Sithithaworn, P.; Kaitsopit, N.; Andrews, R.H.; Petney, T.N (2014). Liver Flukes: Clonorchis and
Opisthorchis. In Toledo, Rafael; Fried, Bernard. Digenetic Trematodes. New York (US): Springer. pp. 153200. ISBN 978-I-49-390914-8

91. Rivolta, S. (1884). Sopra una specie di Distoma nel gatto e nel cane [About the species of Distoma in the cat and in the dog]. Giornale di Anatomia Fisiologica e Patologia degli Animali. 16: 20-28.

92. Sripa, B.; Tesana, S.; Yurlova, N.; Nawa, Y. (2017). A historical review of small liver fluke infections in humans. Parasitology International. Online. doi:Io.IoI6/ j.parint.2017.01.004

93. Looss, A. (1899). Weitere Beiträge zur Kenntniss der Trematoden-Fauna Aegyptens, zugleich Versuch einer natürlichen Gliederung des Genus Distomum Retzius [Further contributions to the knowledge of the trematode fauna of Egypt...]. Zoologische Jabrbücher. Abteilung für Anatomie und Ontogenie der Tiere. 12: 52I784. doi:I0.5962/bhl.part.2037

94. Stiles, Ch. W.; Hassall, A. (1896). Notes on Parasites-4246. The Veterinary Magazine. 3 (3): I5I-I58.

95. Askanazy, M. (1906). Weitere Mittheilungen über die Quellen der Infektion mit Distomum felineum. Schriften der Physikalisch-Ökonomischen Gesellschaft zu Königsberg. 46: I27-I3I.

96. Ciurea, J. (1917). Die Auffindung der Larven von Opisthorchis felineus, Pseudamphistomum danubiense und Metorchis albidus und die morphologische Entwicklung dieser Larven $\mathrm{zu}$ den geschlechtsreifen Würmern [Discovery of the larvae of Opisthorchis felineus, Pseudamphistomum danubiense and Metorchis albidus and their morphological development to mature worms]. Zeitschrift für Infektionskrankheiten, parasitäre Krankheiten und Hygiene der Haustiere. 18 (3): 30I-333.

97. Vogel, H. (1932). Ueber den ersten Zwischenwirt und die Zerkarie von Opisthorchis felineus Riv. [First intermediate host and cercaria of Opisthorchis felineus Riv.]. Archiv für Schiffs- und Tropen-Hygiene. 36 (Iо): 558$56 \mathrm{I}$.

98. Vogel, H. (1937). Beobachtungen ueber die Lebensgeschichte von Opisthorchis felineus in Ostpreussen [On the life-history of Opisthorchis felineus in East Prussia]. Zentralblatt für Bakteriologie, Parasitenkunde, Infektionskrankheiten und Hygiene. 138 (3/4): 250-254.

99. Verdun, P.; Bruyant, L. (1907). Existence de la Douve $\mathrm{du}$ Chat (Opisthorchis felineus Riv.) au Tonkin. Son association chez l'homme avec la Douve de Chine 
(Clonorchis sinensis Cobb.). Comptes Rendus des Séances de la Société de Biologie (Paris). 62: 704-705.

Ioo.Verdun, P.; Bruyant, L. (1908). La douve du chat Opisthorchis felineus (Riv.) existe au Tonkin et s' observe chez l'homme. Archives de Parasitologie. 12: 125-134.

IOI.Leiper, E.T. (I915). Notes of the occurrence of parasites presumably rare in man. Journal of the Royal Army Medical Corps. 24 (6): 569-575. doi:Io.II36/jramc-24-o607

I02.Kerr, W.F.J. (1916). Intestinal parasites in Northern Siam. Transactions of the Royal Society of Tropical Medicine and Hygiene. 9 (3): 82-89. doi:Io.Ior6/Soo359203(16)90038-5

I03.Sripa, B.; Nawa, Y.; Sithithaworn, P.; Andrews, R.; Brindley, P. J. (2OI2). Discovery of human opisthorchiasis: A mysterious history. Parasitology International. 6I (I): 3-4. doi:Io.IoI6/j.parint.20II.08.oI2

104.Prommas, C. (1927). Report of a case of Opisthorchis felineus in Siam. Annals of Tropical Medicine ES Parasitology. 2I (I): 9-IO. doi:10.1080/00034983.1927.11684513

I05.Bedier, E.; Chesneau, P. (1929). Distomatose hépatique a Opist $[\mathrm{h}]$ orchìs au Laos (á Vientiane et Thakhek) [Opisthorchis infection of the liver in Laos]. Bulletin de la Société de Pathologie Exotique. 22 (5): 33I-334.

I06.Sadun, E.H. (1953). Preliminary survey of helminthic diseases in Thailand. Journal of Parasitology. 39 (4): 4243.

I07.Sadun, E.H. (1954). The epidemiology of Opisthorchis viverrini in Thailand. Journal of Parasitology. 40 (5): 30 -40 .

I08.Harinasuta, C.; Vajrasthira, S. (1960). Opisthorchiasis in Thailand. Annals of Tropical Medicine \& Parasitology. 54 (I): I0O-IO5. doi:I0.I080/00034983.1960.11685962

I09.Vajrasthira, S.; Harinasuta, C.; Komiya, Y. (196I). The morphology of the metacercaria of Opisthorchis viverrini, with special reference to the excretory system. $A$ nals of Tropical Medicine ES Parasitology. 55 (4): 4134I8. doi:10.1080/00034983.1961.I1686068
Iı.. Wykoff, D.E.; Harnisuta, C.; Juttijudata, P.; Winn, M.M. (1965). Opisthorchis viverrini in Thailand-the life cycle and comparison with O.felineus. The Journal of Parasitology. 5r: 207-214. doi: 10.2307/3276083

III. Mordvinov, V. A.; Yurlova, N. I.; Ogorodova, L. M.; Katokhin, A. V. (20I2). Opisthorchis felineus and Metorchis bilis are the main agents of liver fluke infection of humans in Russia. Parasitology International. 6I (I): 2531. doi:Io.IoI6/j.parint.2011.07.021

II2. Askanazy, M. (I900). Über infektion des Menschen mit Distomum felineum (sibiricum) in Ostpreussen und ihren Zusammenhang mit Leberkrebs [On infection of humans with Distomum felineum (sibiricum) in East Prussia and their connection with liver cancer]. Zentralblatt für Bakteriologie, Parasitenkunde, Infektionskrankbeiten und Hygiene. 28: 49I-502.

II3. Viranuvatti, V.; Mettiyawongse, S. (1953). Observations on two cases of Opisthorchiasis in Thailand. Annals of Tropical Medicine Ef Parasitology. 47 (3): 291-293. doi:10.1080/00034983.1953.11685570

I44.Viranuvatti, V.; Kshemsant, D.; Bhamarapravati, N. (1955). Retention cyst of liver caused by opisthorchiasis associated with carcinoma; case report. The American Journal of Gastroenterology. 23 (5): 442-446.

II5. Sadun, E.H. (1955). Studies on Opisthorchis viverrini in Thailand. American Journal of Hygiene. 62 (2): 8I-IIs.

II6.Vatanasapt, V.; Tangvoraphonkchai, V.; Titapant, V.; Pipitgool, V.; Viriyapap, D.; Sriamporn, S. (1990). A high incidence of liver cancer in Khon Kaen Province, Thailand. The Southeast Asian Journal of Tropical Medicine and Public Health. 2I (3): 489-494.

II7. Srivatanakul, P.; Parkin, D. M.; Jiang, Y.-Z.; Khlat, M.; Kao-Ian, U-T.; Sontipong, S.; Wild, C. (199I). The role of infection by Opisthorchis viverrini, hepatitis B virus, and aflatoxin exposure in the etiology of liver cancer in Thailand. A correlation study. Cancer. 68 (II): 24II24I7. doi:Io.IOO2/I097-0I42(I99II2OI)68:II<24II::AIDCNCR282068III4>3.0.CO;2-o 